\title{
Ammonium Toxicity in Bacteria
}

\author{
Tim Müller, ${ }^{1,2}$ Britta Walter, ${ }^{1,3}$ Astrid Wirtz, ${ }^{1}$ Andreas Burkovski ${ }^{1,3}$ \\ ${ }^{1}$ Institut für Biochemie, Universität zu Köln, Zülpicher Str. 47, 50674 Köln, Germany \\ ${ }^{2}$ International Max Planck Research School, Max-Planck-Institut für Züchtungsforschung, Carl-von-Linné-Weg 10, 50829 Köln, Germany \\ ${ }^{3}$ Lehrstuhl für Mikrobiologie, Friedrich-Alexander-Universität Erlangen-Nürnberg, Staudtstr. 5, 91058, Erlangen, Germany
}

Received: 12 October 2005 / Accepted: 22 December 2005

\begin{abstract}
Although an excellent nitrogen source for most bacteria, ammonium was-in analogy to plant and animal systems - assumed be detrimental to bacteria when present in high concentrations. In this study, we examined the effect of molar ammonium concentrations on different model bacteria, namely, Corynebacterium glutamicum, Escherichia coli, and Bacillus subtilis. The studied bacteria are highly resistant to ammonium. When growth was impaired upon addition of molar $\left(\mathrm{NH}_{4}\right)_{2} \mathrm{SO}_{4}$ concentrations, this was not caused by an ammonium-specific effect but was due to an enhanced osmolarity or increased ionic strength of the medium. Therefore, it was concluded that ammonium is not detrimental to $C$. glutamicum and other bacteria even when present in molar concentrations.
\end{abstract}

Ammonium (in this communication, the term "ammonium" is used in a general sense, including $\mathrm{NH}_{4}{ }^{+}$and $\mathrm{NH}_{3}$; distinct ammonium species are indicated by chemical formula) is the preferred nitrogen source for most bacteria and fungi, and also plants acquire ammonium as a nitrogen source from the soil [35]. When present in high concentrations, diffusion of $\mathrm{NH}_{3}$, which is in equilibrium with $\mathrm{NH}_{4}{ }^{+}$, across the cytoplasmic membrane into the cell is sufficient to promote growth. In a situation of ammonium limitation, diffusion becomes negligible and special carriers are synthesized in bacteria, fungi, and plants (for a recent review, see [36]).

However, ammonium is a paradoxical nutrient, because it is notorious for its cytotoxic effects. Furthermore, active transport of ammonium can to lead to a harmful energy-wasting futile cycling when accumulated ammonium diffuses across the cytoplasmic membrane back into the medium. Sensitivity to ammonium is discussed to be a universal phenomenon; however, it is well investigated only in plant and animal systems [36], whereas the situation in bacteria is less clear.

Correspondence to: Andreas Burkovski; email: aburkov@biologie. uni-erlangen.de
Our group has been studying nitrogen metabolism and ammonium transport in corynebacteria for several years, with a strong focus on Corynebacterium glutamicum [6-8]. This mycolic acids-containing actinomycete is closely related to important pathogens such as Corynebacterium diphtheriae and Mycobacterium tuberculosis. In contrast to these species, C. glutamicum is safe to handle and not pathogenic. Different $C$. glutamicum strains are used for the industrial production of amino acids, e.g., more than 1,500,000 tons of L-glutamate and 560,000 tons of L-lysine in the year 2003 [11]. Because of its industrial importance, $C$. glutamicum is extremely well investigated and established as a model organism for actinomycetes and other bacteria of biotechnological relevance. This fact and the use of ammonium as a nitrogen source as well as a $\mathrm{pH}$ regulator (in form of $\mathrm{NH}_{4} \mathrm{OH}$ ) in fermentation media made it interesting for us to investigate the topic of ammonium toxicity in $C$. glutamicum. In this study, the experiments were additionally extended to other species, namely, the Gramnegative model organism Escherichia coli and the Gram-positive Bacillus subtilis.

\section{Materials and Methods}

Bacterial strains and growth conditions. Strains and plasmids used in this study are given in Table 1. Bacteria were routinely grown in 
Table 1. Strains and plasmids used in this study

\begin{tabular}{|c|c|c|}
\hline Strains/plasmids & Relevant genotype/description & Reference/source \\
\hline \multicolumn{3}{|l|}{ C. glutamicum } \\
\hline ATCC 13032 & Wild-type & {$[1]$} \\
\hline $\mathrm{LN} \Delta \mathrm{GDH}$ & ATCC $13032 \Delta g d h$ & kindly provided by L. Nolden \\
\hline MJ6-18 & ATCC $13032 \Delta a m t R$ & {$[13]$} \\
\hline $\mathrm{TM} \Delta \mathrm{gdh} \Delta \mathrm{g} \ln \mathrm{A}$ & ATCC $13032 \Delta g d h-\Delta g \ln A$ & This study \\
\hline \multicolumn{3}{|l|}{ E. coli } \\
\hline MG1655 & $\mathrm{K} 12$ wild type $\lambda^{-} \mathrm{F}^{-} r p h-1$ & {$[15]$} \\
\hline \multicolumn{3}{|l|}{ B. subtilis } \\
\hline 168 & Wild type & DSMZ, Braunschweig \\
\hline \multicolumn{3}{|l|}{ Plasmids } \\
\hline $\mathrm{pK} 18 \Delta \mathrm{g} \ln \mathrm{A}$ & $\begin{array}{l}\text { Deletion vector } \mathrm{pK} 18 \mathrm{mobsacB} \\
\text { carrying the flanking regions of } \\
\text { C. glutamicum glnA for generation } \\
\text { of chromosomal deletions, } \mathrm{Kn}^{\mathrm{R}}\end{array}$ & {$[12]$} \\
\hline
\end{tabular}

$\mathrm{Km}^{\mathrm{R}}$, resistance to kanamycin.

shaking flasks at $30^{\circ} \mathrm{C}\left(\right.$ C. glutamicum and B. subtilis) or $37^{\circ} \mathrm{C}($ E. coli).

For $C$. glutamicum growth tests, a fresh culture in BHI medium (Difco, Detroit, MI) was used to inoculate minimal medium (per liter $42 \mathrm{~g}$ MOPS, $20 \mathrm{~g}\left(\mathrm{NH}_{4}\right)_{2} \mathrm{SO}_{4}, 5 \mathrm{~g}$ urea, $0.5 \mathrm{~g} \mathrm{~K}_{2} \mathrm{HPO}_{4} \times 3 \mathrm{H}_{2} \mathrm{O}, 0.5 \mathrm{~g}$ $\mathrm{KH}_{2} \mathrm{PO}_{4}, 0.25 \mathrm{~g} \mathrm{MgSO}_{4} \times 7 \mathrm{H}_{2} \mathrm{O}, 0.01 \mathrm{~g} \mathrm{CaCl}_{2}, 50 \mathrm{~g}$ glucose, $0.2 \mathrm{mg}$ biotin, $10 \mathrm{mg} \mathrm{FeSO}_{4}, 10 \mathrm{mg} \mathrm{MnSO}_{4}, 1 \mathrm{mg} \mathrm{ZnSO}_{4}, 0.2 \mathrm{mg} \mathrm{CuSO}_{4}, 0.02$ $\mathrm{mg} \mathrm{NiCl} \times 6 \mathrm{H}_{2} \mathrm{O}, 0.09 \mathrm{mg} \mathrm{H}_{3} \mathrm{BO}_{3}, 0.06 \mathrm{mg} \mathrm{CoCl}{ }_{2} \times 6 \mathrm{H}_{2} \mathrm{O}, 0.009 \mathrm{mg}$ $\mathrm{NaMoO}_{4} \times 2 \mathrm{H}_{2} \mathrm{O}$; pH adjusted to pH 7.0 using $\mathrm{NaOH}$; [16]) for overnight growth. This culture, with an overnight $\mathrm{OD}_{600}$ of approximately 25 to 30 , was used to inoculate fresh medium containing different concentrations of either $\left(\mathrm{NH}_{4}\right)_{2} \mathrm{SO}_{4}$ or $(\mathrm{Na})_{2} \mathrm{SO}_{4}$. The medium for glutamine-auxotrophic $\Delta g d h-\Delta g \ln A$ strain $\mathrm{TM} \Delta \mathrm{gdh} \Delta \mathrm{g} \ln \mathrm{A}$ was supplemented with $100 \mathrm{~mm}$ L-glutamine.

E. coli MG1655 cells were grown in medium described by Davis and Mingioli [9] containing $8.02 \mathrm{~g} \mathrm{~K}_{2} \mathrm{HPO}_{4} \times 3 \mathrm{H}_{2} \mathrm{O}, 3.0 \mathrm{~g} \mathrm{KH}_{2} \mathrm{PO}_{4}$, $0.3 \mathrm{~g}$ tri-sodium citrate $\times 2 \mathrm{H}_{2} \mathrm{O}, 1.06 \mathrm{~g}\left(\mathrm{NH}_{4}\right)_{2} \mathrm{SO}_{4}, 0.1 \mathrm{~g} \mathrm{MgSO}_{4} \times 7$ $\mathrm{H}_{2} \mathrm{O}$, and $5.0 \mathrm{~g}$ glucose per liter. An inoculation scheme similar to C. glutamicum was applied with an LB medium [28] over day culture, an overnight minimal medium culture, and inoculation of fresh minimal medium containing different concentrations of either $\left(\mathrm{NH}_{4}\right)_{2} \mathrm{SO}_{4}$ or $(\mathrm{Na})_{2} \mathrm{SO}_{4}$.

B. subtilis 168 was grown in medium containing $15.0 \mathrm{~g}$ peptone, $3.0 \mathrm{~g}$ yeast extract, $6.0 \mathrm{~g} \mathrm{NaCl}$, and $1.0 \mathrm{~g}$ glucose per liter (adjusted to $\mathrm{pH}$ 7.5) in the presence of different concentrations of either $\left(\mathrm{NH}_{4}\right)_{2} \mathrm{SO}_{4}$ or $(\mathrm{Na})_{2} \mathrm{SO}_{4}$.

Determination of methylammonium uptake. Methylammonium uptake measurements were carried out as described earlier [31]. In brief, cells grown in minimal medium were harvested by centrifugation, washed with MES/Tris buffer (adjusted with $\mathrm{NaOH}$ to $\mathrm{pH}$ 8.0), and suspended in the same buffer to a final $\mathrm{OD}_{600}$ of 3-4. Uptake measurements were started by the addition of $100 \mu \mathrm{m}$ or $1500 \mu \mathrm{m}\left[{ }^{14} \mathrm{C}\right]$-labeled methylammonium. Samples were taken in 15 -s time intervals over a period of $2 \mathrm{~min}$. The cells were separated from the surrounding medium by rapid filtration, washed twice, and subjected to scintillation counting.

Ammonium concentration measurements. For determination of intracellular ammonium, $2 \mathrm{~mL}$ of a $C$. glutamicum culture $\left(\mathrm{OD}_{600}\right.$ approximately 4-5) were harvested by centrifugation. The weight of the pellet was determined, and the cells were resuspended in $100 \mu \mathrm{L}$ of an aqueous $0.1 \% \mathrm{~N}$-cetyl- $\mathrm{N}, \mathrm{N}, \mathrm{N}$-trimethylammonium bromide solution.
After incubation for $10 \mathrm{~min}$ at room temperature, cell debris was removed by centrifugation. The ammonium concentrations of this supernatant as well as of the culture medium obtained in the first centrifugation step were determined by reversed-phase highperformance liquid chromatography (HPLC) using a protocol based on the method described by Lindroth and Mopper [21]. Ammonium was labeled by pre-column derivatization using ortho-phthaldialdehyde (OPA). For separation, the Agilent 1100 system (Agilent, Waldbronn) with a LiChrosher RP $18(150 \times 3 \mathrm{~mm}, 5 \mathrm{~mm})$ column (Merck, Darmstadt) and $60 \%$ methanol as mobile phase with a flow rate of 0.8 $\mathrm{mL} / \mathrm{min}$ at $40^{\circ} \mathrm{C}$ were used. Column effluents were monitored with a G1321A Fluorimeter (Agilent, Waldbronn) at an excitation wavelength of $330 \mathrm{~nm}$ and a detection wavelength of $455 \mathrm{~nm}$.

From the ammonium concentrations measured by HPLC, the intracellular ammonium concentration was calculated. As a prerequisite for this calculation, the ratio of internal cell volume to total pellet volume had to be determined. For this purpose, the distribution of a membrane permeable probe, $\left[{ }^{3} \mathrm{H}\right]$-labeled water, and a membrane impermeable one, $\left[{ }^{14} \mathrm{C}\right]$-labeled taurine, was measured. These experiments revealed that $62.0 \pm 1.0 \%$ of the cell pellet consisted of surrounding medium.

General molecular biology techniques and construction of a $g d h$ $\operatorname{gln} \boldsymbol{A}$ mutant strain. For plasmid isolation, transformation, and cloning standard techniques were used $[2,28]$. Competent C. glutamicum cells were prepared according to van der Rest and co-workers [34]. In order to generate a C. glutamicum strain that is impaired in ammonium assimilation, a $g \ln A$ deletion was introduced in $g d h$ deletion strain $\mathrm{LN} \Delta \mathrm{GDH}$ using plasmid $\mathrm{pK} 18 \Delta \mathrm{g} \ln \mathrm{A}[12]$ and the protocol for the generation of unmarked genomic gene deletions described by Schäfer and co-workers [29].

RNA isolation and hybridization experiments. Total RNA was prepared after disruption of the C. glutamicum cells by glass beads using the RNeasy Mini Kit as recommended by the supplier (Qiagen, Hilden). The RNA was either size-fractionated using agarose gels containing formaldehyde and blotted onto positively charged nylon membranes or spotted directly onto nylon membranes using a Schleicher \& Schuell (Dassel) Minifold I Dot Blotter. Hybridization of digoxigenin-labeled RNA probes was detected with a Fuji luminescent image analyzer LAS1000 or Kodak X-OMAT X-ray films using alkaline phosphatase conjugated anti-digoxigenin Fab 

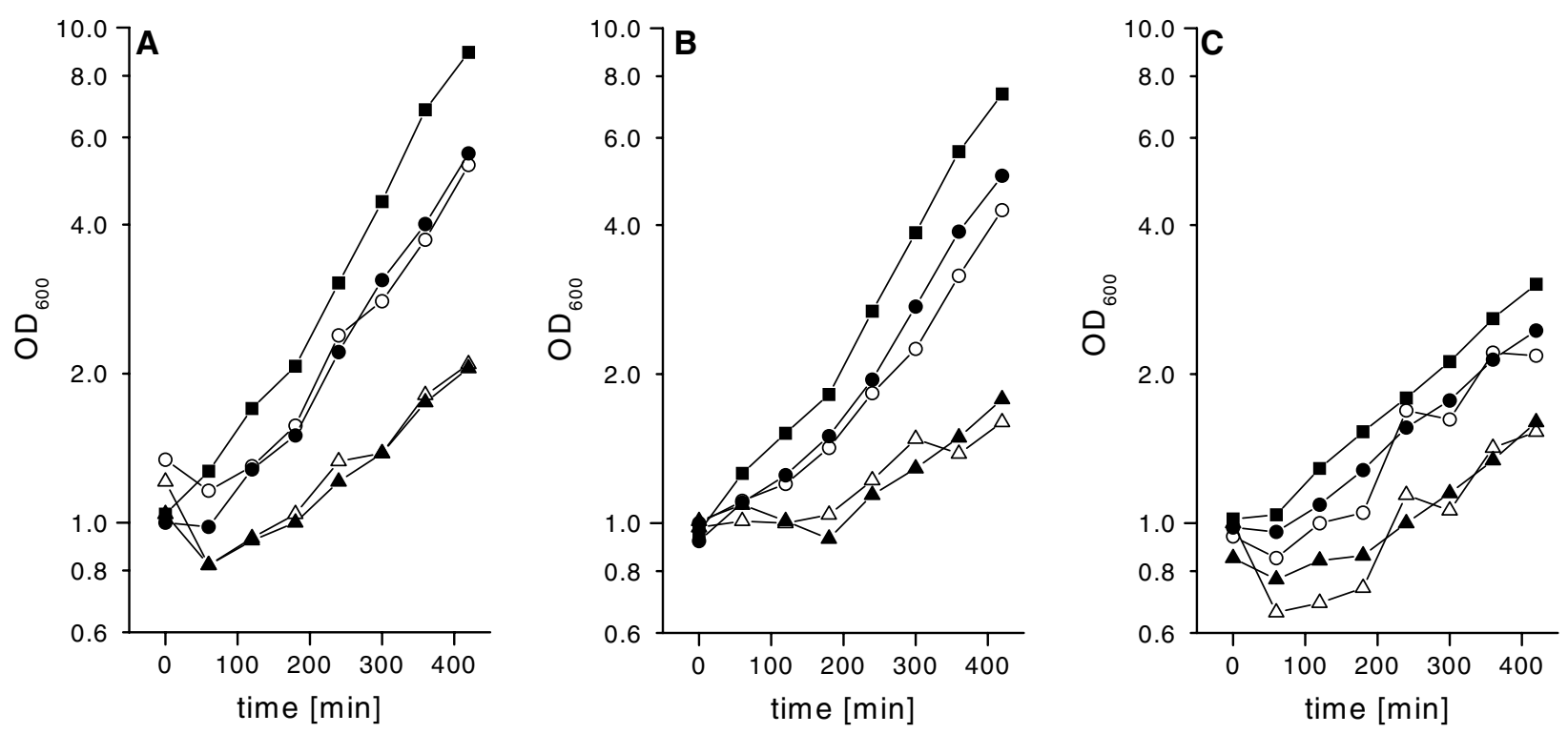

Fig. 1. Effect of increasing solute concentrations on growth of different C. glutamicum strains. (A) C. glutamicum wild-type ATCC 13032, (B) $a m t R$ deletion strain MJ6-18, (C) $\Delta g d h-\Delta g \ln A$ deletion strain $\mathrm{TM} \Delta \mathrm{gdh} \Delta \mathrm{gln}$ A. Cells were grown in MOPS-buffered minimal medium with $0.25,0.5$, and $1.0 \mathrm{M}\left(\mathrm{NH}_{4}\right)_{2} \mathrm{SO}_{4}$ (closed square, circle, and triangle), $0.25 \mathrm{M}\left(\mathrm{NH}_{4}\right)_{2} \mathrm{SO}_{4}+0.25 \mathrm{M}(\mathrm{Na})_{2} \mathrm{SO}_{4}$ (open circle), and $0.25 \mathrm{M}\left(\mathrm{NH}_{4}\right)_{2} \mathrm{SO}_{4}+0.75 \mathrm{M}$ $(\mathrm{Na})_{2} \mathrm{SO}_{4}$ (open triangle). The medium of $\Delta g d h-\Delta g \ln A$ deletion strain $\mathrm{TM} \Delta \mathrm{gdh} \Delta \mathrm{g} \ln \mathrm{A}$ was additionally supplemented with $100 \mathrm{~mm}$ L-glutamine. Experiments were carried out at least in duplicate. Standard errors were below $10 \%$.

fragments and CSPD as light-emitting substrate as recommended by the supplier (Roche Diagnostics, Mannheim).

\section{Results and Discussion}

Rising ammonium concentrations impair growth of C. glutamicum. A prerequisite for a specific toxic effect of ammonium is its presence in the cell. Evidence for rapid flux of $\mathrm{NH}_{3}$ across biomembranes was already obtained about 100 years ago (for review, see [18, 20]), and high $\mathrm{NH}_{3}$ diffusion rates were determined in different bacteria, e.g., in Bacillus firmus, Rhodobacter spheroides, and Synechococcus R-2 [26, 27]. C. glutamicum has, compared to these already investigated species, a more complex cell wall structure with a mycolic-acid layer functioning as an additional permeability barrier [25].

The concentration of ammonium inside the $C$. glutamicum cytoplasm was determined. Because rapid diffusion was expected, a centrifugation assay was chosen. When the ammonium concentration in the wild type grown in minimal medium (151 mM ammonium) was tested, $142 \mathrm{~mm}$ ammonium was determined inside the cell, which corresponds almost to an equilibrium. Vice versa, a rapid diffusion of ammonia from the cytoplasm into the medium was observed, when cells were transferred from nitrogen-rich to ammonium-free medium (data not shown). Therefore, it was concluded that the C. glutamicum cell envelope is no barrier for ammonium flux, and high external ammonium concentrations correspond to a high internal ammonium pool in this organism.

To test the ammonium susceptibility of $C$. glutamicum, the strains ATCC 13032, MJ6-18, and $\mathrm{TM} \Delta \mathrm{gdh} \Delta \mathrm{g} \ln \mathrm{A}$ were chosen for growth experiments (Fig. 1A-C). Type strain ATCC13032, used as wild type control, has an intact nitrogen regulation and assimilates ammonium mainly via the glutamate dehydrogenase pathway when grown in nitrogen-rich minimal medium. Ammonium transporter-encoding genes are not expressed under the experimental conditions used. Strain MJ6-18 carries a genomic amtR deletion [13], which leads to the lack of the master regulator of nitrogen control, AmtR. As a consequence, genes encoding the enzymes of the glutamine synthetase-glutamate synthase pathway (GS/GOGAT) [3, 24] and ammonium carriers AmtA and AmtB [23, 31] are constitutively expressed. Double deletion strain $\mathrm{TM} \Delta \mathrm{gdh} \Delta \mathrm{g} \ln \mathrm{A}$ is lacking the ammonium assimilation enzymes glutamate dehydrogenase and glutamine synthetase (GS I). This leads to a permanent situation of nitrogen limitation resulting in the expression of ammonium transporter-encoding genes even in the presence of externally added L-glutamine (Fig. 2). Cultures of these strains were supplemented with increasing amounts of $\left(\mathrm{NH}_{4}\right)_{2} \mathrm{SO}_{4}$ and their growth was monitored (Fig. 1A-C). The standard minimal media for $C$. glutamicum already contain between 


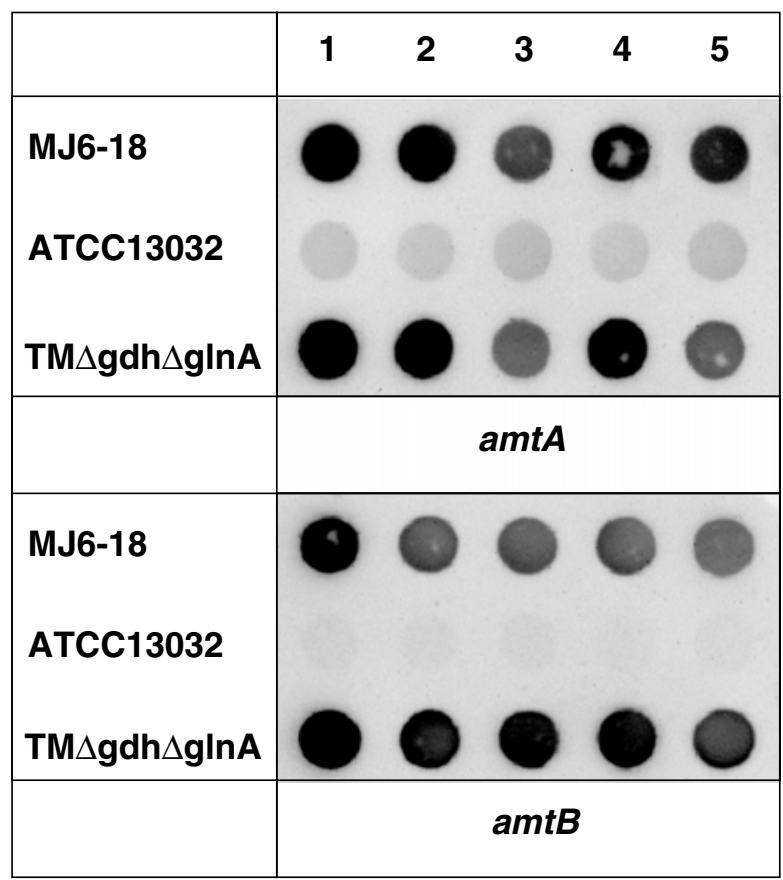

Fig. 2. Expression of ammonium transporter-encoding genes in different $C$. glutamicum strains. Equal amounts $(2.5 \mu \mathrm{g})$ of total RNA prepared from cells grown in minimal medium with $0.25,0.5$, and 1.0 м $\left(\mathrm{NH}_{4}\right)_{2} \mathrm{SO}_{4}$ (1-3) and a mixture of $0.25 \mathrm{M}\left(\mathrm{NH}_{4}\right)_{2} \mathrm{SO}_{4}+0.25 \mathrm{M}$ $(\mathrm{Na})_{2} \mathrm{SO}_{4}$ as well as $0.25 \mathrm{M}\left(\mathrm{NH}_{4}\right)_{2} \mathrm{SO}_{4}+0.75 \mathrm{M}(\mathrm{Na})_{2} \mathrm{SO}_{4}(4,5)$ were spotted on nitrocellulose membranes and probed for amt $A$ and $a m t B$ expression. Whereas expression of these genes is repressed by the global nitrogen regulator AmtR in the wild-type ATCC 13032, constitutive $a m t A$ and $a m t \mathrm{~B}$ transcription is observed in $a m t R$ deletion strain MJ6-18 and strain $\mathrm{TM} \Delta \mathrm{gdh} \Delta \mathrm{gln} A$.

200 and $500 \mathrm{~mm}$ ammonium, indicating a high ammonium resistance. Thus, a slight effect on growth of the different strains was observed in the presence of $1 \mathrm{M}$ ammonium $\left(0.5 \mathrm{M} \quad\left(\mathrm{NH}_{4}\right)_{2} \mathrm{SO}_{4}\right)$. Addition of $2 \mathrm{M}$ ammonium $\left(1 \mathrm{M}\left(\mathrm{NH}_{4}\right)_{2} \mathrm{SO}_{4}\right)$ resulted in a lag-phase of approximately $3 \mathrm{~h}$ and a decreased growth rate. Although wild-type ATCC 13032 and $\Delta a m t R$ strain MJ618 showed comparable doubling times, growth of ammonium assimilation-defect mutant $\mathrm{TM} \Delta \mathrm{gdh} \Delta \mathrm{g} \ln \mathrm{A}$ was always reduced. Obviously, this strain has a general growth problem even when supplemented with $100 \mathrm{~mm}$ L-glutamine, most likely because the relatively slow L-glutamine uptake system [30]. Nevertheless, in all three strains, concentration-dependent growth impairment in response to ammonium addition was observed.

The ammonium effect on $C$. glutamicum is the result of an increasing osmolarity or ionic strength of the medium. In principle, differences in the cellular capacity to metabolize ammonium, e.g., in the wild type and glutamine synthetase-glutamate dehydrogenase mutant $\mathrm{TM} \Delta \mathrm{gdh} \Delta \mathrm{gln} \mathrm{A}$, were expected to be reflected by different abilities to cope with high ammonium concentrations. Because such strain-specific differences were not observed, we assumed that the growth retardation caused by the addition of ammonium sulfate was the result of a secondary effect, for example, of ionic or osmotic stress. In fact, adding rising amounts of sodium sulfate to the cells led to identical growth rates compared with the effect of the corresponding ammonium sulfate concentrations (Fig. 1A-C). Consequently, the growth retardation observed upon addition of $\left(\mathrm{NH}_{4}\right)_{2} \mathrm{SO}_{4}$ cannot be attributed to a specific toxicity of ammonium.

The effect of a putative futile cycling of ammonium is negligible in $\boldsymbol{C}$. glutamicum. As indicated by the growth experiments presented above, ammonium has no specific toxic effect, independent of the genetic background of the strains used. This is astonishing, because synthesis of ammonium transporters AmtA and $\mathrm{AmtB}$ is deregulated in $a m t R$ deletion strain MJ6-18 [13]. In strain $\mathrm{TM} \Delta \mathrm{gdh} \Delta \mathrm{g} \ln A$, the situation is even more extreme, because $a m t A$ and $a m t B$ are transcribed (Fig. 2) while the ammonium assimilating enzyme glutamine synthetase and glutamate dehydrogenase are lacking. This is a putative dangerous situation for the two strains, because intracellular ammonium accumulation by an uptake system may create a harmful energy-wasting futile cycle, in which energydependent uptake is counteracted by diffusion of $\mathrm{NH}_{3}$ out of the cell, leading to a breakdown of the membrane potential [19].

A simple explanation for the ability of MJ6-18 and $\mathrm{TM} \Delta \mathrm{gdh} \Delta \mathrm{gln}$ A to survive exposure to high ammonium concentrations would be a downregulation of ammonium transporters at the level of activity. To study this hypothesis, transport rates were determined using the $\left[{ }^{14} \mathrm{C}\right]$-labeled ammonium analog methylammonium. Although the wild-type ATCC 13032 and strain MJ6-18 revealed no differences in growth (Fig. 1), transport measurements revealed that ammonium uptake systems are inactive in the wild-type ATCC 13032 but active in strain MJ6-18 (Fig. 3). Although no uptake of methylammonium at all was determined for strain ATCC 13032, transport rates of 0.9 and $1.1 \mathrm{nmol}(\mathrm{mg}$ dry weight) ${ }^{-1} \mathrm{~min}^{-1}$ were determined for MJ6-18 at $100 \mu \mathrm{M}$ and of 8.5 and $12.1 \mathrm{nmol}(\mathrm{mg} \text { dry weight })^{-1}$ $\mathrm{min}^{-1}$ at $1500 \mu \mathrm{M}\left[{ }^{14} \mathrm{C}\right]$-labeled methylammonium. The absence of any growth deficit of strain MJ6-18 compared to the wild type suggests that ammonium futile cycling is not occurring in the studied $C$. glutamicum strain or its putative negative effect is negligible. However, because ammonium transport was measured 


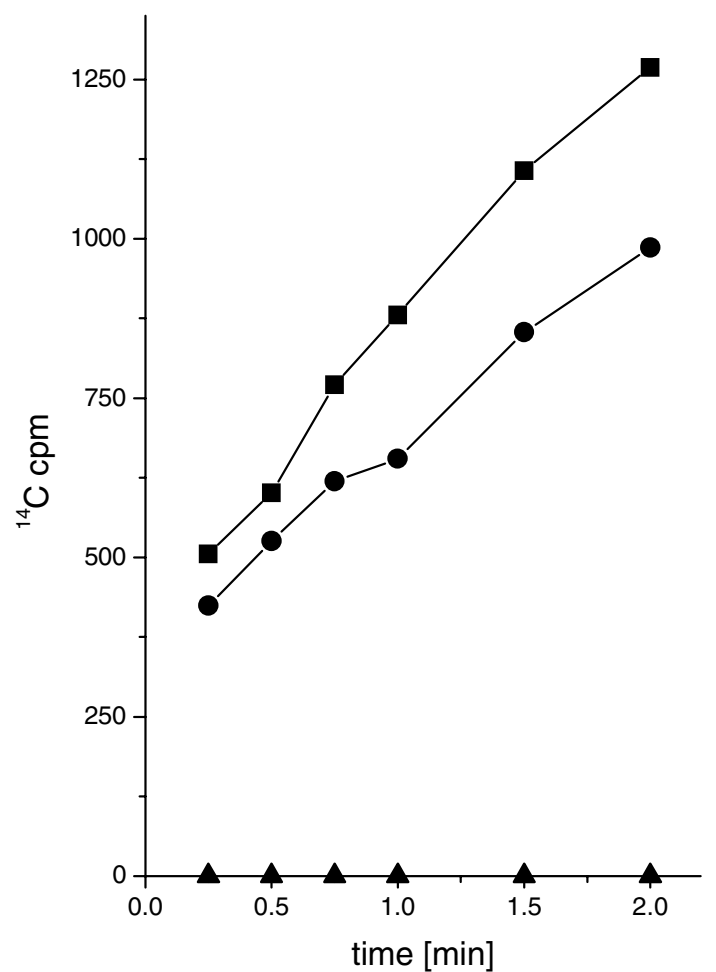

Fig. 3. Methylammonium uptake of $C$. glutamicum wild-type ATCC13032 and amtR deletion strain MJ6-18. Cells were grown in nitrogen-rich minimal medium, and uptake measurements were carried out in the presence of 100 or $1500 \mu \mathrm{M}\left[{ }^{14} \mathrm{C}\right]$-labeled methylammonium. Although methylammonium transport was not detectable in wild-type cells grown under these conditions (triangles), a considerable uptake was observed in $C$. glutamicum strain MJ6-18 (100 $\mu \mathrm{M}\left[{ }^{14} \mathrm{C}\right]$ methylammonium: circles, $1500 \mu \mathrm{M} \quad\left[{ }^{14} \mathrm{C}\right]$ methylammonium: squares $)$. Experiments were carried out in duplicate with identical results.

indirectly, an activity regulation of ammonium transport cannot be excluded.

Because of the lack of the ammonium-assimilating enzymes glutamate dehydrogenase and glutamine synthetase, strain $\mathrm{TM} \Delta \mathrm{gdh} \Delta \mathrm{gln} A$ expresses $a m t A$ and $a m t B$ even during ammonium surplus conditions. As a consequence, this strain showed methylammonium uptake (data not shown), but no indications for an ammonium futile cycle were detected. The interpretation in comparison to the wild type is less clear as in strain MJ6-18 because of the general growth defect of these cells.

Ammonium toxicity in E. coli and B. subtilis. To investigate whether $C$. glutamicum is especially resistant to ammonium or whether the lacking toxicity is a general phenomenon found in bacteria, the effect of high ammonium concentrations was studied in the Gramnegative model bacterium E. coli and in the Grampositive model organism B. subtilis.
Table 2. Growth rates of E. coli strain MG1655 and B. subtilis strain 168 in medium with different concentrations of $\left(\mathrm{NH}_{4}\right)_{2} \mathrm{SO}_{4}$ and $(\mathrm{Na})_{2} \mathrm{SO}_{4}$

\begin{tabular}{lll}
\hline Added salt & $\mathrm{t}_{\mathrm{D}}$ E. coli [min] & $\mathrm{t}_{\mathrm{D}}$ B. subtilis [min] \\
\hline $50 \mathrm{~mm}\left(\mathrm{NH}_{4}\right)_{2} \mathrm{SO}_{4}$ & $72 / 72$ & $48 / 36$ \\
$250 \mathrm{mM}\left(\mathrm{NH}_{4}\right)_{2} \mathrm{SO}_{4}$ & $66 / 72$ & $48 / 48$ \\
$50 \mathrm{~mm}\left(\mathrm{NH}_{4}\right)_{2} \mathrm{SO}_{4}+$ & $90 / 90$ & $42 / 36$ \\
$200 \mathrm{mM}\left(\mathrm{Na}_{2} \mathrm{SO}_{4}\right.$ & & \\
$375 \mathrm{~mm}\left(\mathrm{NH}_{4}\right)_{2} \mathrm{SO}_{4}$ & $132 / 102$ & $84 / 126$ \\
$50 \mathrm{mM}\left(\mathrm{NH}_{4}\right)_{2} \mathrm{SO}_{4}+$ & $b^{b}$ & $78 / 84$ \\
$\quad 325 \mathrm{mM}\left(\mathrm{Na}_{2} \mathrm{SO}_{4}\right.$ & & \\
$500 \mathrm{mM}\left(\mathrm{NH}_{4}\right)_{2} \mathrm{SO}_{4}$ & $260 / 186$ & ${ }^{b} / 600$ \\
$50 \mathrm{~mm}\left(\mathrm{NH}_{4}\right)_{2} \mathrm{SO}_{4}+$ & ${ }^{b} /^{b}$ & $b / 600$ \\
$450 \mathrm{mM}\left(\mathrm{Na}_{2} \mathrm{SO}_{4}\right.$ & & \\
\hline
\end{tabular}

${ }^{a}$ All experiments were carried out in duplicate (biological replicates) and doubling times (in min) are shown.

${ }^{b}$ growth was recovered after approximately 6 to $8 \mathrm{~h}$ lag-phase.

Standard minimal media used for E. coli contain ammonium concentrations in the low millimolar range. When these were increased to up to $500 \mathrm{~mm}$ ammonium (250 mm $\left.\left(\mathrm{NH}_{4}\right)_{2} \mathrm{SO}_{4}\right)$, no detrimental effect on growth was observed. Only when $750 \mathrm{~mm}$ ammonium was added, a decrease in growth rate was observed. As in C. glutamicum, this is caused by osmotic or ionic stress rather than by ammonium toxicity, as shown by the addition of sodium sulfate to cells, which led to even severe effects (Table 2). It might be speculated that the less drastic effect of ammonium compared to sodium is the result of a faster equilibration due to diffusion of $\mathrm{NH}_{3}$ and resulting smaller osmotic gradients between medium and cytoplasm.

For B. subtilis, a standard complex medium was supplemented with $\left(\mathrm{NH}_{4}\right)_{2} \mathrm{SO}_{4}$. Also in this case, a specific ammonium effect was not observed (Table 2). As in E. coli, addition of $750 \mathrm{~mm}$ and $1000 \mathrm{~mm}$ ammonium ( $375 \mathrm{~mm}$ and $500 \mathrm{~mm}\left(\mathrm{NH}_{4}\right)_{2} \mathrm{SO}_{4}$ ) impaired growth; however, similar effects were observed when $\left(\mathrm{NH}_{4}\right)_{2} \mathrm{SO}_{4}$ was exchanged against $(\mathrm{Na})_{2} \mathrm{SO}_{4}$.

In summary, our results indicate that ammonium is not toxic for E. coli and B. subtilis, and growth retardations observed in the presence of molar concentrations are the result of general osmotic or ionic effects as in the case of C. glutamicum.

\section{Conclusions}

Ammonium is in contrast to the situation in animal cells (e. g. see [22]) and plants (e.g., $[4,5])$ not toxic for the studied model bacteria C. glutamicum, E. coli, and B. subtilis, even in molar concentrations. Because most bacteria prefer ammonium as nitrogen source and some species even produce ammonium, for example, rhizobia 
and cyanobacteria by $\mathrm{N}_{2}$-fixation and proteolytic clostridia by amino acid fermentation, we assume that ammonium resistance is a general phenomenon in bacteria.

In ammonium-rich medium, the diffusion of $\mathrm{NH}_{3}$ across the cytoplasmic membrane is sufficient to promote bacterial growth, and wild-type cells of $E$. coli [32], B. subtilis [10], and C. glutamicum [23, 31] synthesize special ammonium transporters only in a situation of nitrogen limitation. As one reason for this strict regulation, prevention of a putative energy-wasting futile cycling of ammonium was discussed. In such a situation, $\mathrm{NH}_{4}{ }^{+}$would be transported into the cell by an energy-dependent uptake mechanism and would subsequently diffuse across the cytoplasmic membrane back into the medium in the form of $\mathrm{NH}_{3}$. For C. glutamicum, such an effect of ammonium cycling could not be shown. Mutant strains, which showed in contrast to the wild-type methylammonium uptake during ammonium surplus in the medium, were not impaired in growth. A possible explanation of this observation is an energyindependent transport by ammonium channels, which facilitates diffusion, rather than by permeases, which concentrate ammonium inside the cell by an energydependent transport mechanism. This kind of transport mechanism was first suggested by Soupene and coworkers for ammonium transporter AmtB from Salmonella typhimurium $[32,33]$ and was further supported by the recently published structure of E. coli AmtB [17] as well as by transport data [14].

\section{ACKNOWLEDGMENTS}

The authors wish to thank Stephanie Kadow and Christine Eilender for technical support and Reinhard Krämer for continuous interest and support.

\section{Literature Cited}

1. Abe S, Takayama K, Kinoshita S (1967) Taxonomical studies on glutamic acid producing bacteria. J Gen Microbiol 13:279-301

2. Ausubel FM, Brent R, Kingston RE, Moore DD, Seidman JG, Smith JA, Struhl K (1987) Current protocols in molecular biology. New York: Greene Publishing Associates and Wiley Interscience, John Wiley and Sons

3. Beckers G, Nolden L, Burkovski A (2001) Glutamate synthase of Corynebacterium glutamicum is not essential for glutamate synthesis and is regulated by the nitrogen status. Microbiology 147:2961-2970

4. Britto DT, Siddiqi MY, Glass ADM, Kronzucker HJ (2001) Futile transmembrane $\mathrm{NH}_{4}{ }^{+}$cycling: A cellular hypothesis to explain ammonium toxicity in plants. Proc Natl Acad Sci USA 98:42554258

5. Britto DT, Konzucker $\mathrm{HJ}$ (2002) $\mathrm{NH}_{4}{ }^{+}$toxicity in higher plants: a critical review. J Plant Physiol 159:567-584

6. Burkovski A (2003) I do it my way: Regulation of ammonium uptake and ammonium assimilation in Corynebacterium glutamicum. Arch Microbiol 179:83-88
7. Burkovski A (2003) Ammonium assimilation and nitrogen control in Corynebacterium glutamicum and its relatives: an example for new regulatory mechanisms in actinomycetes. FEMS Microbiol Rev 27:617-628

8. Burkovski A (2005) Nitrogen metabolism and its regulation. In: Bott M, Eggeling L (eds) Handbook of Corynebacterium glutamicum. Boca Raton, FL: CRC Press, pp 99-118

9. Davis BD, Mingioli ES (1950) Mutants of Escherichia coli requiring methionine or vitamin $\mathrm{B} 12$. J Bacteriol 60:17-28

10. Detsch C, Stülke J (2003) Ammonium utilization in Bacillus subtilis: transport and regulatory functions of $\mathrm{NrgA}$ and $\mathrm{NrgB}$. Microbiology 149:3289-3297

11. Hermann $T$ (2003) Industrial production of amino acids by coryneform bacteria. J Biotechnol 104:155-172

12. Jakoby M, Tesch M, Sahm H, Krämer R, Burkovski A (1997) Isolation of the Corynebacterium glutamicum glnA gene encoding glutamine synthetase I. FEMS Microbiol Lett 154:81-88

13. Jakoby M, Nolden L, Meier-Wagner J, Krämer R, Burkovski A (2000) AmtR, a global repressor in the nitrogen regulation system of Corynebacterium glutamicum. Mol Microbiol 37:964977

14. Javelle A, Thomas G, Marini A-M, Krämer R, Merrick M (2005) In vivo functional characterization of the Escherichia coli ammonium channel AmtB: evidence for metabolic coupling of AmtB to glutamine synthetase. Biochem J 390:215-222

15. Jensen KF (1993) The Escherichia coli K-12 "wild types" W3110 and MG1655 have an rph frameshift mutation that leads to pyrimidine starvation due to low pyrE expression levels. J Bacteriol 175:3401-3407

16. Keilhauer C, Eggeling L, Sahm H (1993) Isoleucine synthesis in Corynebacterium glutamicum: molecular analysis of the ilvB-ilvNilvC operon. J Bacteriol 175:5595-5603

17. Khademi S, O'Connell J III, Remis J, Robles-Colmenares Y, Miercke LJW, Stroud RM (2005) Mechanism of ammonia transport by Amt/MEP/Rh: Structure of AmtB at $1.35 \mathrm{~A}$. Science 305:1587-1594

18. Kleiner D (1981) The transport of $\mathrm{NH}_{3}$ and $\mathrm{NH}_{4}{ }^{+}$across biological membranes. Biochim Biophys Acta 639:41-52

19. Kleiner D (1985) Bacterial ammonium transport. FEMS Microbiol Rev 32:87-100

20. Kleiner D (1993) Ammonium transport systems - an overview. In: Bakker EP (ed) Alkali cation transport systems in prokaryotes. Boca Raton, FL: CRC Press

21. Lindroth P, Mopper K (1979) High performance liquid chromatography determination of subpicomole amounts of amino acids by precolumn fluorescence derivatization with $o$-phthaldialdehyde. Anal Chem 51:1667-1674

22. Martinelle K, Häggström L (1993) Mechanisms of ammonia and ammonium ion toxicity in animal cells: Transport across cell membranes. J Biotechnol 30:339-350

23. Meier-Wagner J, Nolden L, Jakoby M, Siewe R, Krämer R, Burkovski A (2001) Multiplicity of ammonium uptake systems in Corynebacterium glutamicum: Role of Amt and AmtB. Microbiology 147:135-143

24. Nolden L, Farwick M, Krämer R, Burkovski A (2001) Glutamine synthetases in Corynebacterium glutamicum: transcriptional control and regulation of activity. FEMS Microbiol Lett 201:9198

25. Puech V, Chami M, Lemassu A, Laneelle MA, Schiffler B, Gounon P, Bayan N, Benz R, Daffe M (2001) Structure of the cell envelope of corynebacteria: importance of the non-covalently bound lipids in the formation of the cell wall permeability barrier and fracture plane. Microbiology 147:1365-1382 
26. Ritchie RJ, Gibson J (1987) Permeability of ammonia, methylamine and ethylamine in the cyanobacterium Synechococcus R-2 (Anacystis nidulans) PCC7942. J Membr Biol 95:131-142

27. Ritchie RJ, Gibson J (1987) Permeability of ammonia and amines in Rhodobacter spheroides and Bacillus firmus. Arch Biochem Biophys 258:322-341

28. Sambrook J, Fritsch EF, Maniatis T (1989) Molecular cloning: A laboratory manual, 2nd ed. Cold Spring Harbor, NY: Cold Spring Harbor Laboratory Press

29. Schäfer A, Tauch A, Jäger W, Kalinowski J, Thierbach G, Pühler A (1994) Small mobilizable multi-purpose cloning vectors derived from the Escherichia coli plasmids pK18 and pK19: Selection of defined deletions in the chromosome of Corynebacterium glutamicum. Gene 145:69-73

30. Siewe RM, Weil B, Krämer R (1995) Glutamine uptake by a sodium-dependent secondary transport system in Corynebacterium glutamicum. Arch Microbiol 164:98-103

31. Siewe RM, Weil B, Burkovski A, Eikmanns BJ, Eikmanns M, Krämer R (1996) Functional and genetic characterization of the (methyl)ammonium uptake carrier of Corynebacterium glutamicum. J Biol Chem 271:5398-5403

32. Soupene E, He L, Yan D, Kustu S (1998) Ammonia acquisition in enteric bacteria: physiological role of the ammonium/methylammonium transport B (AmtB) protein. Proc Natl Acad Sci USA 95:7030-7034

33. Soupene E, Lee H, Kustu S (2002) Ammonium/methylammonium transport (Amt) proteins facilitate diffusion of $\mathrm{NH}_{3}$ bidirectionally. Proc Natl Acad Sci USA 99:3926-3931

34. van der Rest ME, Lange C, Molenaar D (1999) A heat shock following electroporation induces highly efficient transformation of Corynebacterium glutamicum with xenogeneic plasmid DNA. Appl Microbiol Biotechnol 52:541-545

35. von Wirén N, Gazzarrini S, Gojon A, Frommer WB (2000) The molecular physiology of ammonium uptake and retrieval. Curr Opin Plant Biol 3:254-261

36. von Wirén N, Merrick M (2004) Regulation and function of ammonium carriers in plants, yeast and bacteria. Trends Curr Genet 9:95-120 